\title{
PHYTOPLANKTON METRICS RESPONSE TO THE INCREASING PHOSPHORUS AND NITROGEN GRADIENT IN SHALLOW LAKES*
}

\author{
Agnieszka Napiórkowska-Krzebietke ${ }^{1}$, \\ Agnieszka Pasztaleniec ${ }^{2}$, Andrzej Hutorowicz ${ }^{1}$ \\ ${ }^{1}$ Department of Hydrobiology \\ Inland Fisheries Institute in Olsztyn \\ ${ }^{2}$ Institute of Environmental Protection \\ National Research Institute in Warsaw
}

\begin{abstract}
A new phytoplankton-based method (the Phytoplankton Metric for Polish Lakes PMPL) for the ecological status assessment of lakes has been developed in Poland. This method has not been validated and tested on independent data, hence the aim of the study was to check the applicability of this method and the sensitivity of different phytoplankton metrics along pressure gradient. Phytoplankton data were collected from 33 Polish lowland lakes (20 stratified, 13 non-stratified), during the growth season in the period from 2005 to 2009. The biomass of phytoplankton was calculated from cell volume measurements and chlorophyll a concentration was determined spectrophotometrically by the alcohol method. Total nitrogen and total phosphorus concentrations were determined by standard methods (PN-EN ISO 6878:2006p.7 and PN-EN 25663:2001, respectively) and water transparency was measured using a Secchi disk.

For comparability, an ecological status was determined according to three phytoplankton-based methods: Polish, German and Hungarian. Polish metrics showed a strong correlation with the other metrics (German, Hungarian), which are broadly and successfully used for assessment in Europe. However, a statistically significant correlation was found between all the metric values and the main parameters: total phosphorus, total nitrogen and Secchi disk visibility. The metrics based on quantitative phytoplankton features were more sensitive to the growth of eutrophication than others, based on indicator taxa. Total phosphorus demonstrated a stronger relationship with the tested metrics than total nitro-
\end{abstract}

dr inż. Agnieszka Napiórkowska-Krzebietke, Department of Hydrobiology, Inland Fisheries Institute, Oczapowskiego Street 10, 10-719 Olsztyn, Poland, e-mail: akrzebietke@ infish.com.pl

*This article has been party financed from Norway Grants, project No. PNRF-220-A I- 1/07. 
gen. Phytoplankton metrics reacted quite well to pressure gradients because of the decreasing tendency of metric values along the $\mathrm{TP}$ and $\mathrm{TN}$ gradient and an increasing tendency along the Secchi disk visibility gradient. The multimetric PMPL may be recommended as useful for the assessment of the ecological status of Polish lakes.

Key words: WFD, ecological status assessment, phytoplankton-based method, PMPL, PSI, $\mathrm{Q}$ Index.

\title{
ODPOWIEDŹ METRIKSÓW FITOPLANKTONOWYCH NA WZROST GRADIENTU FOSFORU I AZOTU W JEZIORACH PLYTKICH
}

\begin{abstract}
Abstrakt
W Polsce opracowano nowa metodę do oceny stanu ekologicznego jezior na podstawie fitoplanktonu (polski multimetriks fitoplanktonowy - PMPL). Metoda ta nie została zwalidowana i przetestowana na niezależnych danych. Celem badań było sprawdzenie możliwości zastosowania tej metody oraz wrażliwości różnych metriksów fitoplanktonowych na gradient presji. Dane fitoplanktonowe zebrano z 33 polskich jezior nizinnych (w tym 20 stratyfikowanych i 13 niestratyfikowanych), w sezonie wegetacyjnym w latach 2005-2009. Biomasę fitoplanktonu oszacowano metodą pomiaru objętości komórek, stężenie chlorofilu $a \mathrm{w}$ wodzie określono spektrofotometryczną metodą alkoholową. Zawartość fosforu i azotu ogólnego oznaczono standardowymi metodami (odpowiednio PN-EN ISO 6878:2006p.7 i PN-EN 25663:2001), natomiast widzialność wyznaczono z użyciem krążka Secchi'ego. Ocenę stanu ekologicznego określono według trzech metod fitoplanktonowych: polskiej, niemieckiej i węgierskiej.

Polskie metriksy wykazywały silną korelację z innymi metriksami (niemieckimi i węgierskim), które sa szeroko stosowane do oceny stanu ekologicznego w Europie. Statystycznie istotne korelacje wykazano również między wartościami metriksów a głównymi parametrami presji, fosforem i azotem ogólnym oraz widzialnościa krażka Secchi'ego. Metriksy oparte na cechach ilościowych fitoplanktonu były bardziej wrażliwe na wzrost stopnia eutrofizacji niż inne, oparte na taksonach wskaźnikowych. Fosfor ogólny wykazywał silniejszy związek z testowanymi metriksami niż azot ogólny. Zaobserwowano tendencję do zmniejszania się wartości metriksów wzdłuż gradientu fosforu i azotu ogólnego oraz tendencję do wzrostu wzdłuż gradientu widzialności. Świadcza one o tym, że metriksy fitoplanktonowe dobrze reaguja na presję, a multimetriks PMPL może być rekomendowany jako przydatny do oceny stanu ekologicznego polskich jezior.
\end{abstract}

Słowa kluczowe: RDW, ocena stanu ekologicznego, metoda fitoplanktonowa, PMPL, PSI, $\mathrm{Q}$ indeks.

\section{INTRODUCTION}

Phytoplankton, like other biological quality elements, responds to multiple environmental factors and, being a good indicator of water quality with respect to eutrophication, is required for the implementation of the Water Framework Directive (WFD) - EC2000/60/WE. Several methods based on phytoplankton parameters (chlorophyll $a$, biomass, indicator taxa, phytoplankton assemblage structure) for the ecological status assessment of lakes are 
still being developed or have already been applied in the EU countries (PADISÁK et al. 2006, MischKe et al. 2008, PтACNiK et al. 2009). At present, the assessment criteria in Poland are based only on chlorophyll $a$ concentration in water as a measure of phytoplankton abundance (The Regulation... 2008, No. 162, Item 1008). In 2009, on a commission from the Chief Inspectorate for Environmental Protection, a phytoplankton-based method for the assessment of the ecological status of lakes was developed (the Phytoplankton Metric for Polish Lakes - PMPL; Hutorowicz et al. 2011), which, apart from chlorophyll $a$, also accounts for the total phytoplankton biomass and the biomass of Cyanoprokaryota. The latter index covers the biomass of bluegreen algae and their share in the total phytoplankton biomass. Therefore, it may be treated as an element in the assessment based on the taxonomic composition of phytoplankton assemblage. Each newly developed method for assessment ought to be a suitable tool to measure the composed anthropogenic damage and should be checked before being included in monitoring programs (NöGES et al. 2009). The Polish method has not yet been validated and tested on independent data. Hence, the aim of this study was to check the usefulness of the Polish method for the ecological status assessment and compare the sensitivity of different phytoplankton metrics to the increase of phosphorus and nitrogen gradient in Polish shallow lakes. Additionally, Secchi disk visibility was taken into account as an important factor of light conditions in water.

\section{MATERIALS AND METHODS}

Phytoplankton and chlorophyll $a$ data were collected from 33 different lowland lakes (20 stratified, 13 non-stratified) during the growth season in the period from 2005 to 2009 (totally 39 - 'lake years'). The lakes were situated in north-eastern Poland, on postglacial deposits, belonging to the Western Europe Unit and Eastern Europe Unit. These data were obtained within the framework of the National Environmental Monitoring and within the framework of the Polish-Norwegian project tilted 'deWELopment' - 'Development and validation of methods for integrated assessment of ecological status of rivers and lakes to support river basin management plans'.

According to the Water Framework Directive 2000/60/WE requirement, lakes are classified as:

- lowland lakes;

- small- (50-100 ha) and medium-sized (100-1000 ha) natural reservoirs;

- very shallow (mean depth $<3 \mathrm{~m}$ ) and shallow (mean depth 3-15 m) lakes;

- calcareous lakes;

- lakes with Schindler's ratio (the ratio of total catchment's area to lake volume) below 2 and above 2 ; 
- lakes with different mixing types: stratified and non-stratified, according to Polish abiotic typology (KoladA et al. 2005) belong to 2a, 3a, 5a, 6a and 2b, 3b, $6 \mathrm{~b}$, respectively.

In stratified lakes, samples were collected from the euphotic zone - in spring and autumn and from the epilimnion in summer; in non-stratified lakes they were taken from the whole depth. Samples were taken at onemeter intervals and then integrated. The analyses of phytoplankton were conducted according to UTERMÖHL's method (1958) as described in the guidance standard CEN 2004. The total biomass was calculated from cell volume measurements (PLIŃSKI et al. 1984). Chlorophyll $a$ concentrations were determined spectrophotometrically by the alcohol method (Nusch 1980). Additional samples were collected for chemical analysis of water, mainly total nitrogen and total phosphorus concentrations, which were determined by standard methods. Water transparency was measured using Secchi disks and expressed as the Secchi disk visibility (SV).

The ecological status was determined according to three phytoplanktonbased methods: Polish, German and Hungarian. The new Polish method, called the PMPL, comprises a multimetric based primarily on the quantitative and qualitative parameters which characterise phytoplankton (HuтоRоwICZ et al. 2011). The PMPL includes three constituent metrics: 'Metric Chlorophyll $a$ ' (MC), 'Metric Total Biomass' (MTB) and 'Metric Biomass of Cyanoprokaryota' (MBC), and its final value is an averaged value of these three components.

The German multimetric Phytoplankton Seen Index (PSI) is based on three metrics: 'Metric Biomass' (MB), 'Metric Algal Classes' (MAC) and 'Metric Phytoplankton Taxa Seen Index' - PTSI (Mischke et al. 2008). The 'Metric Biomass' takes into account the total biomass, the mean concentration of chlorophyll $a$ and the maximum concentration of chlorophyll $a$. The 'Metric Algal Classes' is based on the percentage shares in the total biomass of the taxonomic groups typical of the particular water quality classes. The PTSI (Phytoplankton-Taxa-Seen-Index) includes the trophic value of indicator taxa, taking into account their differentiation in the particular abiotic types of lakes.

In the Hungarian method, the Q Index (the phytoplankton assemblage index) was calculated on the basis of Colin Reynolds' concept of functional groups (REYNolds et al. 2002, PADISÁK et al. 2006). The Q Index is based on the ascription of the factor $\mathrm{F}$ to each of the 33 functional groups, depending on the reservoir type and experts' knowledge. It takes into account the relative share of the functional group biomass in the total biomass.

For comparability and further analyses, the values of all metrics were transferred to standardised Ecological Quality Ratio (EQR), which takes into account the measured value and reference value. EQR is set into the range from 0 (the worst) to 1 (the best quality) and class boundaries given in Table 1. 
Table 1

Class boundaries of the ecological status of lakes according to metrics values transferred to standardised

Ecological Quality Ratios

\begin{tabular}{|l|c|}
\hline \multicolumn{1}{|c|}{ EQR normalized } & Ecological status \\
\hline $0.8-1.0$ & high \\
\hline $0.6-0.8$ & good \\
\hline $0.4-0.6$ & moderate \\
\hline $0.2-0.4$ & poor \\
\hline $0-0.2$ & bad \\
\hline
\end{tabular}

The concentrations of total phosphorus and total nitrogen and water transparency (Secchi disk visibility) were chosen as proxies to express the degree of eutrophication. They were used as stressor parameters for phytoplankton development. The analysis of the relationship among the calculated metrics and between them and the environmental parameters was based on the Spearman rank correlation, at the significance level of $p<0.05$. The variability of phytoplankton metric values was analysed with reference to the average seasonal concentrations of nutrients and water transparency. The content of TP ranged from 0.023 to $0.125 \mathrm{mg} \mathrm{dm}^{-3}$ and TN from 0.742 to $3.258 \mathrm{mg} \mathrm{dm}^{-3}$ and SV varied from 0.65 to $4.88 \mathrm{~m}$.

\section{RESULTS}

The tested phytoplankton-based methods classified the surveyed lakes from a high to bad ecological status (Figure 1). The diversified assessments of the status were obtained using different methods because they characterise the assemblage of planctic algae in different ways (in the case of reservoirs with an extremely different quantitative and qualitative phytoplankton structure). Nevertheless, about $40 \%$ of lakes were assessed as being at least in good status (high plus good status) according to both Polish and German methods, whereas only about $25 \%$ were assessed as such by the Q Index. The ecological status of the other natural reservoirs was assessed, depending on the used method, mainly as moderate or poor. The most divergent assessments were obtained with respect to the bad ecological status. The PMPL, PSI and Q Index classified about 6\%, $0 \%$ and 29\% of lakes as being in this state, respectively.

The Polish phytoplankton-based method was closely connected with the German and Hungarian methods. There was a statistically significant correlation observed between the analysed metric values (Table 2). The strongest 


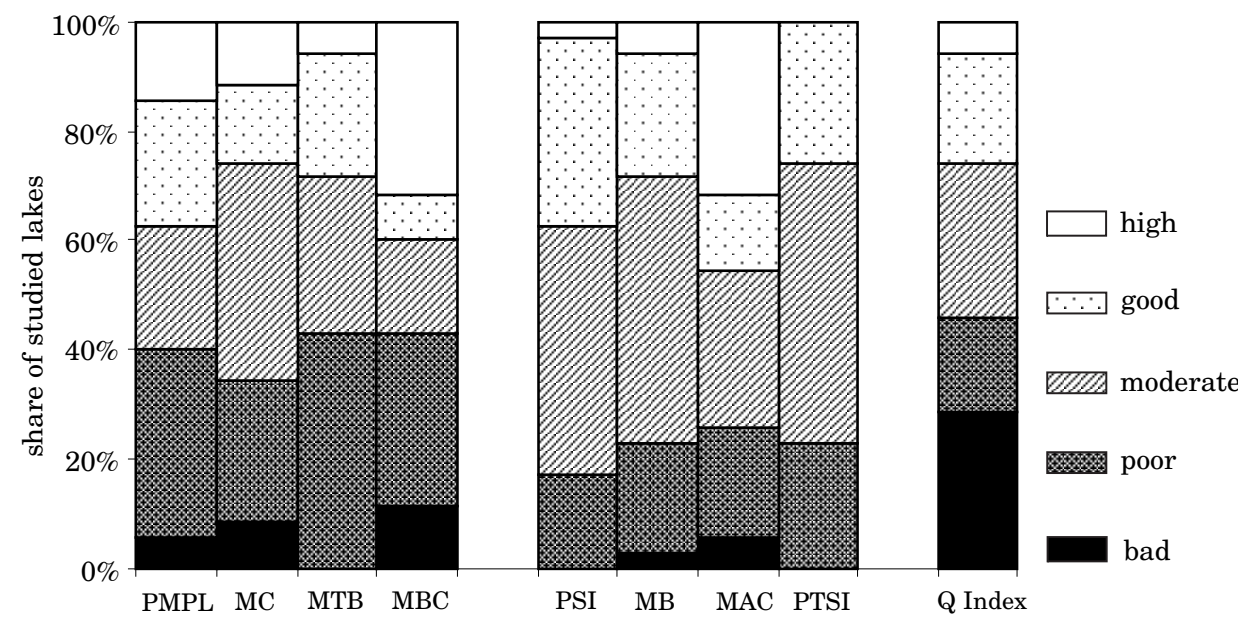

Fig. 1. The ecological status assessment of lakes $(n=39)$ based on three phytoplankton methods: Polish (PMPL), German (PSI) and Hungarian (Q Index)

Explanation: PMPL - Phytoplankton Metric for Polish Lakes, MC - Metric Chlorophyll a, MTB - Metric Total Biomass, MBC - Metric Biomass of Cyanoprokaryota, PSI - Phytoplankton Seen Index, MB - Metric Biomass, MAC - Metric Algal Classes, PTSI - Phytoplankton

Taxa Seen Index

Table 2

The Spearman rank correlation between the metrics of the Polish method and metrics of the other methods, $n=39, p<0.05^{*}$

\begin{tabular}{|l|c|c|c|c|c|}
\hline \multirow{2}{*}{ Tested metrics } & \multicolumn{4}{c|}{ Polish method } \\
\cline { 3 - 6 } & PSI & 0.822 & 0.732 & 0.756 & MBPL \\
\hline \multirow{3}{*}{$\begin{array}{l}\text { German } \\
\text { method }\end{array}$} & MB & 0.834 & 0.830 & 0.786 & 0.731 \\
\cline { 2 - 6 } & MAC & 0.774 & 0.632 & 0.769 & 0.717 \\
\cline { 2 - 6 } & PTSI & 0.281 & 0.277 & 0.095 & 0.301 \\
\hline $\begin{array}{l}\text { Hungarian } \\
\text { method }\end{array}$ & Q Index & 0.650 & 0.432 & 0.567 & 0.698 \\
\hline
\end{tabular}

*Statistically significant correlations $(p<0.05)$ are given in italics (the key to symbols is given in Fig. 1)

dependence was noted between the PMPL and PSI $(r=0.822)$ and their partial metrics, especially based on the chlorophyll $a$ concentration, the total biomass and the biomass of particular taxonomic groups. The exception was the PTSI metric which was dependent on the occurrence of the indicator species, and that one was not significantly correlated between the two method. A distinctly lower, but statistically significant relationship was observed between the Polish multimetric and Q Index describing taxonomic composition. 
In respect of all the tested metrics, a statistically significant correlation was found with the main parameters expressing the eutrophication degree, e.g. total phosphorus, total nitrogen and Secchi disk visibility (Tabble 3). The strongest dependence occurred between the PSI and nutrient concentrations: PSI:TP ( $r=-0.793)$ and PSI:TN ( $r=-0.653)$. A slightly weaker relationship was observed with partial metrics. The lowest statistically significant correlation was noted between the PTSI and all relevant parameters. The Polish multimetric correlated significantly with the total phosphorus and total nitrogen, but the weakest dependence was observed with the MBC metric. The $\mathrm{Q}$ Index also showed quite a good relationship with environmental stressors. In nearly all the cases, total phosphorus was found to be more strongly correlated with phytoplankton metrics than total nitrogen. Regarding the light conditions in water, a significant relationship was found with Secchi disk visibility. The highest correlation coefficient was identified for the $\mathrm{Q}$ Index $(r=0.812)$.

Table 3

The Spearman rank correlation between the main physicochemical parameters and the metrics values, expressed as EQR normalized for all studied lakes, $n=39, p<0.05^{*}$

\begin{tabular}{|l|c|c|c|c|}
\hline \multirow{2}{*}{\multicolumn{2}{|c|}{ Tested metrics }} & \multicolumn{2}{c|}{ Physicochemical parameters } \\
\cline { 2 - 5 } & PMPL & $\begin{array}{c}\text { Secchi disk } \\
\text { visibility }\end{array}$ & total phosphorus & total nitrogen \\
\hline \multirow{4}{*}{ Polish method } & MC & 0.695 & -0.629 & -0.435 \\
\cline { 2 - 5 } & MTB & 0.527 & -0.633 & -0.407 \\
\cline { 2 - 5 } & MBC & 0.599 & -0.544 & -0.445 \\
\hline \multirow{3}{*}{ German method } & PSI & 0.682 & -0.481 & -0.391 \\
\cline { 2 - 5 } & MB & 0.799 & -0.793 & -0.653 \\
\cline { 2 - 5 } & MAC & 0.744 & -0.725 & -0.521 \\
\cline { 2 - 5 } & PTSI & 0.355 & -0.700 & -0.522 \\
\hline \multirow{3}{*}{$\begin{array}{l}\text { Hungarian } \\
\text { method }\end{array}$} & Q Index & 0.812 & -0.502 & -0.386 \\
\hline
\end{tabular}

*Statistically significant correlations $(p<0.05)$ are given in italics (the key to symbols is given in Fig. 1)

Considering the lakes of different water mixing types, the most common statistically significant correlation was found between phytoplankton data and environmental parameters in stratified lakes (Table 4). However, the total phosphorus concentration was slightly more strongly correlated with the Polish and German metrics in non-stratified lakes. The Hungarian index responded reversely. The total nitrogen concentration was significantly related to the PSI in stratified lakes and to the Q Index in non-stratified 
The Spearman rank correlation between the main physicochemical parameters and the metrics values, expressed as EQR normalized for stratified lakes, $n=23$ and non-stratified, $n=16, p<0.05^{*}$

\begin{tabular}{|c|c|c|c|c|c|c|c|}
\hline \multirow{3}{*}{\multicolumn{2}{|c|}{ Tested metrics }} & \multicolumn{6}{|c|}{ Physicochemical parameters } \\
\hline & & \multicolumn{2}{|c|}{ Secchi disk visibility } & \multicolumn{2}{|c|}{ total phosphorus } & \multicolumn{2}{|c|}{ total nitrogen } \\
\hline & & $\mathrm{S}$ & NS & $\mathrm{S}$ & NS & $\mathrm{S}$ & NS \\
\hline \multirow{4}{*}{$\begin{array}{l}\text { Polish } \\
\text { method }\end{array}$} & PMPL & 0.677 & 0.597 & -0.462 & -0.679 & -0.316 & -0.311 \\
\hline & $\mathrm{MC}$ & 0.626 & 0.565 & -0.509 & -0.776 & -0.378 & -0.389 \\
\hline & MTB & 0.686 & 0.509 & -0.462 & -0.568 & -0.457 & -0.261 \\
\hline & MBC & 0.548 & 0.671 & -0.352 & -0.421 & -0.161 & -0.432 \\
\hline \multirow{4}{*}{$\begin{array}{l}\text { German } \\
\text { method }\end{array}$} & PSI & 0.663 & 0.464 & -0.666 & -0.890 & -0.642 & -0.402 \\
\hline & MB & 0.877 & 0.297 & -0.660 & -0.779 & -0.572 & -0.200 \\
\hline & MAC & 0.557 & 0.179 & -0.507 & -0.765 & -0.512 & -0.094 \\
\hline & PTSI & 0.020 & 0.727 & -0.378 & -0.341 & -0.060 & -0.626 \\
\hline $\begin{array}{l}\text { Hungarian } \\
\text { method }\end{array}$ & Q Index & 0.671 & 0.662 & -0.729 & -0.024 & -0.322 & -0.741 \\
\hline
\end{tabular}

$\mathrm{S}$ - stratified lakes, NS - non-stratified lakes, *statistically significant correlations $(p<0.05)$ are given in italics (the key in Fig. 1)

lakes. The composition metrics in the MBC and PTSI usually demonstrated a negligible response to nutrients regarding the two different types of lakes. The relationship with the Secchi disk visibility was stronger in stratified than in non-stratified lakes.

The examined lakes (very shallow and shallow) display considerable gradients in terms of nutrient enrichment and water transparency. Our analysis of the phytoplankton metrics towards the chosen parameters showed significant trends along the eutrophication gradient corresponding to an appropriate ecological status from high to bad, according to the direction of trophy growth. The values of all metrics decreased with the increasing TP and TN gradients, but increased consistently with the Secchi disk visibility gradient (Figures 2,3). The metrics based on quantitative phytoplankton features (biomass and chlorophyll $a$ concentration) of the PMPL (MC, MTB) and PSI (MB, MAC) reacted to the growth of eutrophication degree much stronger than others, based on composition structure (MBC, PTSI) - Figure 2 . 

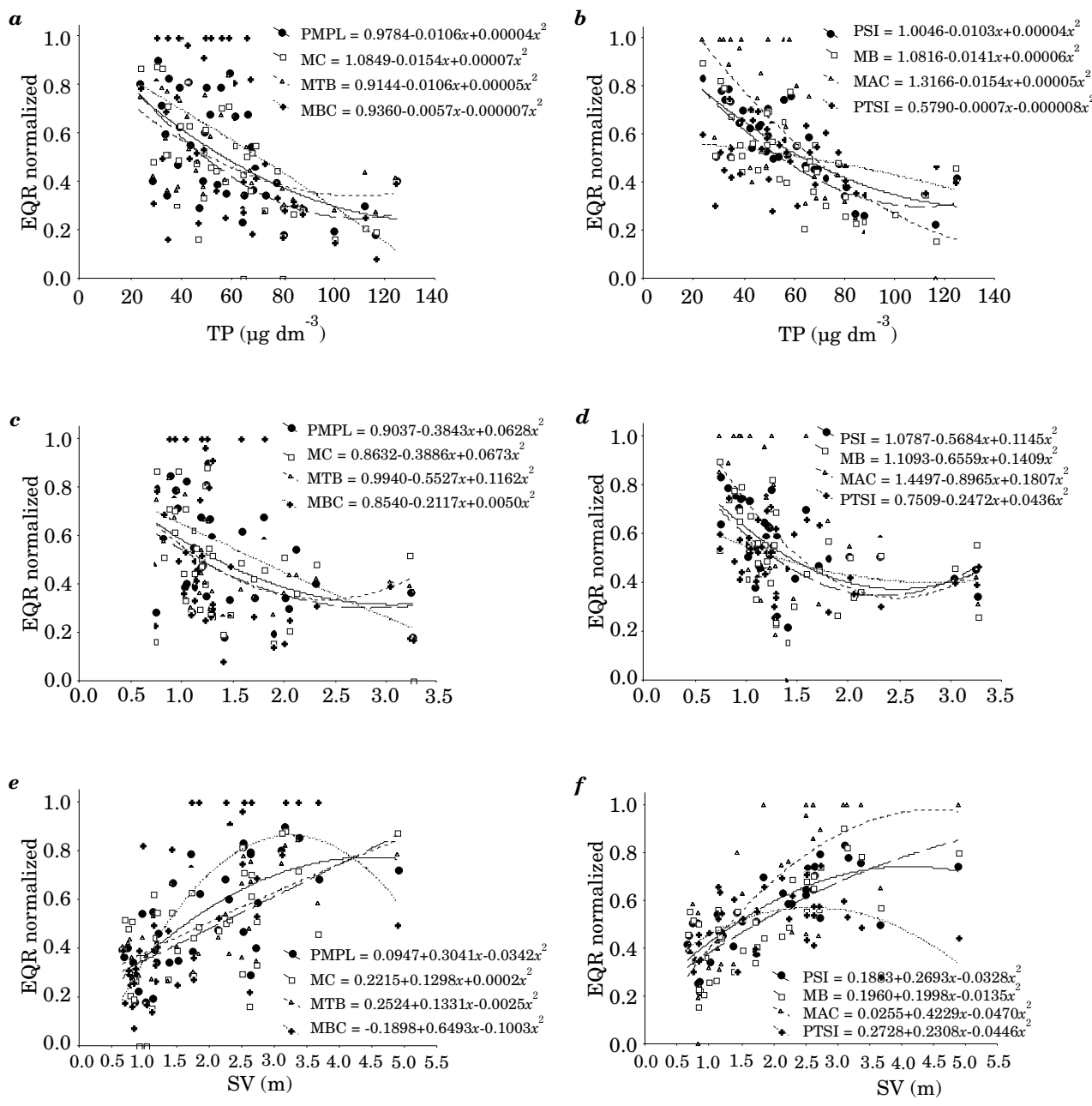

Fig. 2. Relationships for the Polish (PMPL, MC, MTB, MBC) and German (PSI, MB, MAC, PTSI) phytoplankton metrics along the total phosphorus (TP), total nitrogen (TN) and Secchi disk visibility (SV) gradients 

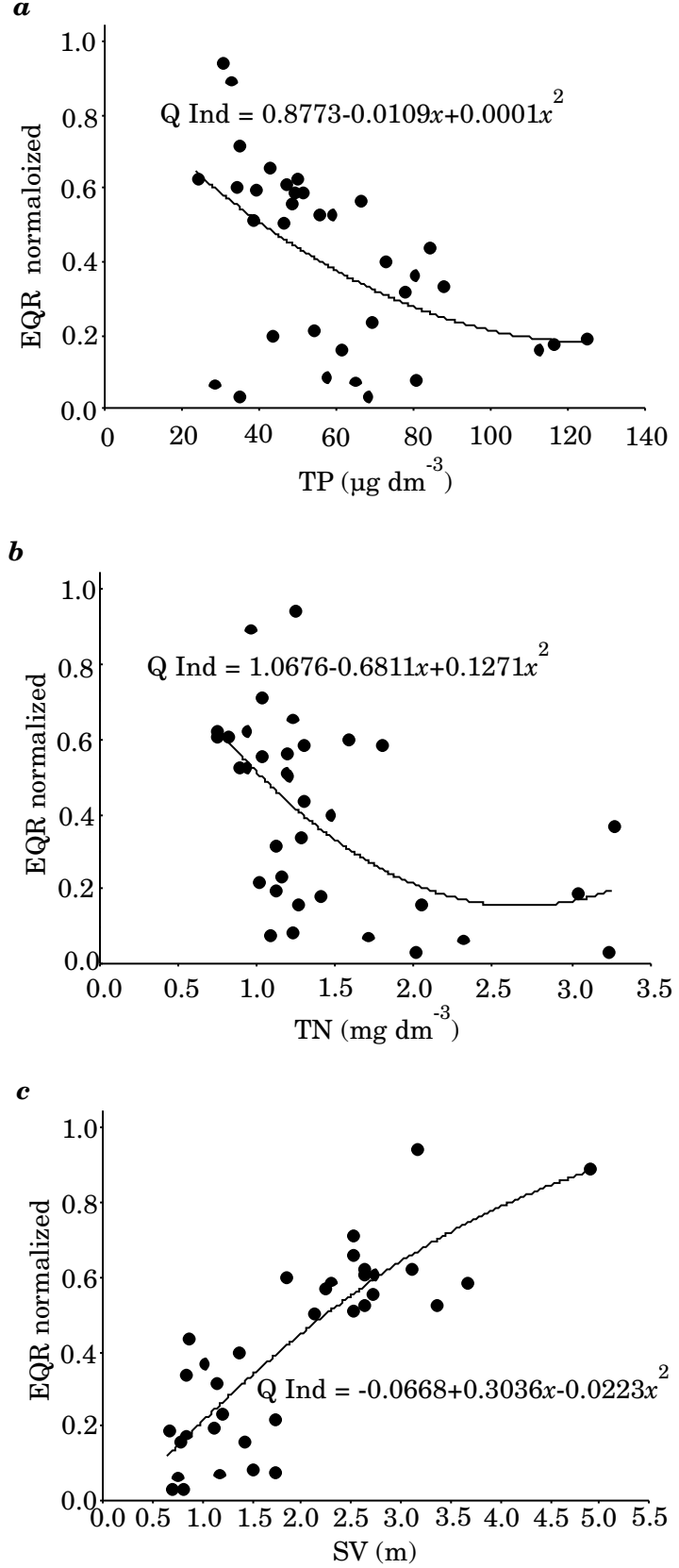

Fig. 3. Relationships for the Hungarian $\mathrm{Q}$ Index along the total phosphorus (TP), total nitrogen $(\mathrm{TN})$ and Secchi disk visibility $(\mathrm{SV})$ gradients 


\section{DISCUSSION}

Phytoplankton, as the earliest component in the water food web, reacts rapidly to nutrient enrichment. Species-specific strategic adaptations to the different physicochemical parameters and nutrient availability allow some estimates of population variability (DEvLIN et al. 2009). Their response to specified environmental conditions are essential to being a very useful indicator. Therefore, according to the WFD planctic algae together with bentic flora, macroinvertebrates and fish are included as the biological quality elements (BQEs) for the ecological status assessment of lakes. Both phytoplankton biomass and taxonomic composition with bloom-forming occurrence should be applied for this purpose (WFD, Annex V). Each BQE (expressed as proper index or metric) relates to different pressures in degree to be operational for water management. Several phytoplankton-based methods for ecological status assessment of lakes, coastal and estuarine water bodies exist in European countries (LePISTÖ et al. 2006, PADISÁK et al. 2006, MischKE et al. 2008, Ptacnik et al. 2009, Devlin et al. 2009). The newly elaborated Polish method corresponds to the conditions and types of lowland lakes in Poland. The applicability of this method is currently being tested using an intercalibration process (EC 2010) to ensure that the 'good' ecological status represents the same level of water quality in different areas in Europe (EC 2005).

Among all the 39 'lake years' only about $40 \%$ of lakes were assessed as having at least a 'good' ecological status. This status is defined as slight changes in the composition and abundance of planktonic taxa compared to the type-specific communities (EC2000/60/WE). The good ecological status is determined on the basis of both biological and non-biological (physicochemical and hydromorphological) elements and is required for all natural surface waters in European countries by 2015. Most of the surveyed lakes demonstrated signs of higher distortion resulting from human activity and the phytoplankton biomass was significantly more disturbed than under conditions of the good status. Persistent blooms occurred in those lakes (NAPIÓRKOWSKA-KRZEBIETKE et al. 2009), up to possible production of toxins producing.

The Polish phytoplankton multimetric and its component metrics showed a strong correlation with the other analysed metrics (German, Hungarian), which are used broadly and successfully for assessment in Europe (CROSSETTI, De M. Bicudo 2008, Hajnal, Padisák 2008, Kaiblinger et al. 2009). The consistency between the lake assessment by the German method and the Polish classification based on chlorophyll $a$ concentration was also found for selected Polish lakes in the previous research (PaszTaleniec, Poniewozik 2010), despite the fact that the German PSI index covers a much larger number of phytoplankton parameters than the PMPL and primarily takes into account a much greater degree the species structure of the algal assemblage. 
The impact of the metric 'Biomass of Cyanoprokaryota' in the final assessment is very significant, as it brings to the assessment elementary information on the structure of the phytoplankton biomass (the share of bluegreen algae in the total biomass). This group of phytoplankton is very important and is commonly used as a partial metric for assessment in Poland as well as in other countries, mainly Belgium, Lithuania and the United Kingdom (EC 2010). The importance of blue-green algae is recognized as a good indicator for phytoplankton response to eutrophication (LYCHE SoLHEIM et al. 2008).

The surveyed lakes are under various anthropogenic pressures, e.g. the predominance of arable land in most of the lakes' catchment areas, existing village buildings, tourist facilities, various forms of tourism and point-sources of pollution entering directly the lakes or the Wel River. Additionally, hydromorphologic differences were also observed between the lakes. A whole range of environmental variables affected the final ecological status assessments of the lakes. This corresponded quite well with the eutrophication degree; as a rule of the thumb, a worse ecological status (worse water quality) equals a higher trophy status. Phosphorus and nitrogen are widely recognized as key nutrients and - for pressure determination - total rather than available forms are used (mostly soluble reactive phosphorus, nitrate and ammonium), which are characterized by much higher lability (Moss et al. 2003). The total phosphorus demonstrated a stronger relationship with the used and tested metrics than total nitrogen, confirming that phosphorus is usually the limiting nutrient for the growth of phytoplankton in lakes (SCHINDler 1977, GuILDFORD, HeCKy 2000). In most cases, phytoplankton is controlled by $\mathrm{P}$ concentrations (e.g. Dokulil, Teubner 2005) and TP can be a very good predictor of its development (LYCHE SOLHEIM et al. 2008, NöGES et al. 2009). Despite this fact, total nitrogen can correlate very strongly with phytoplankton biomass and chlorophyll $a$ concentration (CARSTEnsen, HenriKSEN 2009). The N:P ratio in water columns of the surveyed lakes usually reached values above the critical value of about 17 (ZDANOwsKI 1982). Only in a few cases lower ratios of $\mathrm{N}: \mathrm{P}$ were recorded which, indeed, corresponded quite well with Cyanoprokaryota dominance in the summer phytoplankton of the examined lakes (NAPIóRKOWsKA-KRzEBIETKE et al. 2009). Despite the facts that the Secchi disk visibility reflects effects of both phytoplankton and inorganic and detrital turbidity, as well as dissolved colour substances in the water (Moss et al. 2003) and that phytoplankton is adaptable to low light availability by producing more chlorophyll per unit biomass (GREISBERGER, TEUBNER 2007), the water transparency was also taken into account as a proxy for eutrophication. The visibility of Secchi disk is usually treated as a very convenient summary of many features in lakes.

The current results show a quantitative and qualitative impact-response change across a stressor gradient. In view of the strong correlation between the values of the Polish phytoplankton metrics and the pressure factors, as 
well as the strong correlation between the values of the PMPL and PSI metrics, the PMPL may be recommended as useful for the assessment of the ecological status of lakes.

\section{CONCLUSIONS}

The newly developed Phytoplankton Metric for Polish Lakes (PMPL) is significantly correlated with other widespread metrics (German and Hungarian). The strongest correlation was observed with the Phytoplankton Seen Index (PSI). All phytoplankton metrics were related to stress gradients and a statistically significant correlation was found with the selected physicochemical parameters expressing the degree of eutrophication (total phosphorus, total nitrogen and Secchi disk visibility). The strongest dependence occurred in the case of the PSI multimetric and its components. The decreasing tendency of metrics values along the TP and TN gradient and the increasing tendency along the Secchi disk visibility gradient confirmed the ecologically important relationship to environmental stressors. The partial metrics of the PMPL (MC, MTB) and PSI (MB, MAC) based on quantitative phytoplankton features (chlorophyll $a$ and biomass) were more sensitive to the growth of eutrophication degree than other metrics based on indicator taxa (MBC, PTSI). The Q Index classified the studied lakes more rigorously than the PMPL and PSI, but responded very similarly to a trophy increase.

These conclusions, in turn, enable us to recommend the Phytoplankton Metric for Polish Lakes as a useful method for the assessment of the ecological status of lakes. The intercalibration process of this method will confirm its applicability to assessment of lakes comparable to water quality assessments in different areas of Europe.

\section{Acknowledgements}

The study was financed from Norway Grants under the Norwegian Financial Mechanism (Project No. PNRF - 220 - A I - 1/07) within the "DeWELopment" Project. In addition, data of the Chief Inspectorate of Environmental Protection obtained within the framework of the National Environmental Monitoring were used.

\section{REFERENCES}

Carstensen J., Henriksen P. 2009. Phytoplankton biomass response to nitrogen inputs: a method for WFD boundary setting applied to Danish coastal waters. Hydrobiologia, 633: 137-149.

CEN 2004. Water quality - Guidance standard for the routine analysis of phytoplankton abundance and composition using inverted microscopy (Utermöhl technique) CEN TC 230/WG2/TG3/N83. 
Crossetti L.O., De M. Bicudo C. E. 2008. Phytoplankton as a monitoring tool in a tropical urban shallow reservoir (Garças Pond): the assemblage index application. Hydrobiologia, 610: 161-173.

Devlin M., Barry J., Painting S., Best M. 2009. Extending the phytoplankton tool kit for the UK Water Framework Directive: indicators of phytoplankton community structure. Hydrobiologia, 633:151-168.

Dokulil M.T., Teubner K. 2005. Do phytoplankton communities correctly track trophic changes? An assessment using directly measured and palaeolimnological data. Freshwater Biol., 50: 1589-1593.

EUROPEAN COMMISION 2000. Directive of the European Parliament and of the Council 2000/60/EC establishing a framework for community action in the field of water policy. Official Journal 2000 L 327/1, European Commission, Brussels.

EUROPEAN COMMISION 2005. Common implementation strategy for the water framework directive $(2000 / 60 / e c)$. Guidance on the Intercalibration process 2004-2006. Luxemburg, Office for Official publications of the European Communities. http://circa.europa.eu/Public/irc/env/wfd/library.

EUROPEAN COMMISION 2010. WFD Intercalibration Phase 2: Milestone 2 report (for ECOSTAT meeting 8-9 April 2010), European Commission, Directorate General Jrc and Joint Research Centre, Institute of Environment and Sustainability.

Greisberger S., Teubner K. 2007. Does pigment composition reflect phytoplankton community structure in differing temperature and light conditions in a deep alpine lake? An approach using HPLC and delayed fluorescence (DF) techniques. J. Phycol., 43: 1108-1119 .

GUILDFoRd S.J., HECKY R. E. 2000. Total nitrogen, total phosphorus, and nutrient limitation in lakes and oceans: Is there a common relationship? Limnol. Oceanogr., 45: 1213-1223.

HAJNAL É., PADISÁK J. 2008. Analysis of long-term ecological status of Lake Balaton based on the ALMOBAL phytoplankton database. Hydrobiologia, 599: 227-237.

Hutorowicz A., Napiórkowska-Krzebietke A., Pasztaleniec A., Hutorowicz J., Lyche Solheim A., SkJelbred B. 2011. Phytoplankton. In: Ecological status assessment of the waters in the Wel River catchment. Guidelines for integrated assessment of ecological status of rivers and lakes to support river basin management plans. SoszkA H. (ed). IFI Olsztyn, 143-168. (in Polish)

Kaiblinger C., Anneville O., Tandonleke R., Rimet F., Druart J.C., Guillar J., Dokulil M.T. 2009. Central European water quality indices applied to long-term data from pre-alpine lakes: test and possible improvements. Hydrobiologia, 633: 67-74.

Kolada A., Soszka H., Cydzik D., Goєub M. 2005. Abiotic typology of Polish lakes. Limnologica, 35: $145-150$.

Lepistö L. Hopainen A-L., Vuoristo H., Rekolainen S. 2006. Phytoplankton assemblages as a criterion in the ecological classification of lakes in Finland. Boreal Environ. Res., 11: $35-44$.

Lyche Solheim A., Rekolainen S., Moe S.J., Carvalho L., Phillips G., Ptacnik R., Penning W.E., Toth L.G., O’Toole C., Schartau A-K.L., Hesthagen T. 2008. Ecological threshold responses in European lakes and their applicability for the Water Framework Directive (WFD) implementation: synthesis of lakes results from the REBECCA project. Aquat. Ecol., 42: 317-334.

Mischke U., Riedmüller U., Hoenn E., Schönfelder I., Nixdorf B. 2008. Description of the German system for phytoplankton-based assessment of lakes for implementation of the EU Water Framework Directive (WFD). In: Bewertung von Seen mittels Phytoplankton zur Umsetzung der EU-Wasserrahmenrichtlinie. Mischke U., Nixdorf B. (eds.). Aktuelle Reihe 2/2008, Bad Saarow, Freiburg, Berlin. University of Cottbus, 117-146. 
Moss B.D. et al. 2003. The determination of ecological status in shallow lakes - a tested system (ECOFRAME) for implementation of the European Water Framework Directive. Aquat. Conserv., 13(6): 507-549.

Napiórkowska-Krzebietke A., Pasztaleniec A., Hutorowicz A. 2009. Phytoplankton - element in ecological status assessment for lakes of the Wel River catchment area. Teka Kom. Ochr. Kszt. Środ. Przyr. - OL PAN, 6: 200-2005.

Nöges P., van de Bund W., Cardoso A.C., Solimini A.G., Heiskanen A-S. 2009. Assessment of the ecological status of European surface waters: a work in progress. Hydrobiologia, 633: 197-211.

Nusch E.A. 1980. Comparison of different methods for chlorophyll and phaeopigment determination. Ergebn. Limnol., 14: 14-36.

PAdisák J., Borics G., Grigorszky I., Soróczki-Pintér E. 2006. Use of phytoplankton assemblages for monitoring ecological status of lakes within the Water Framework Directive: the assemblage index. Hydrobiologia, 553: 1-14.

Pasztaleniec A., PoniewoziK M. 2010. Phytoplankton based assessment of the ecological status of four shallow lakes (Eastern Poland) according to Water Framework Directive a comparison of approaches. Limnologica, 40: 251-259.

Pliński M., Picińska J., TARGońSKi L. 1984. Method defining the biomass of marine phytoplankton by means of computers. Zesz. Nauk. WBiNoZ Gdansk University, 10: 129-155. (in Polish)

Ptacnik R., Solimini A.G., Brettum P. 2009. Performance of a new phytoplankton composition metric along a eutrophication gradient in Nordic lakes. Hydrobiologia, 633: 75-82.

Reynolds C.S., Huszar V., Kruk C., Naselli-Flores L., Melo S. 2002. Towards a functional classification of the freshwater phytoplankton. J. Plankton Res., 24: 417-428.

Schindler D.W. 1977. Evolution of phosphorus limitation in lakes. Science, 195: 260-262.

The Regulation of the Minister of the Environment of 20 August 2008 for the status classification of surface water bodies. The Official Journal of the Laws of 2008, No. 162, Item 1008.

UtermöHL H. 1958. Zur Vervollkommung der quantitativen Phytoplankton-Methodik. Mitt. internat. Verein. Limnol., 9: 1-38. (in German)

ZDANOWSKI B. 1982. Variability of nitrogen and phosphorus contents and lake eutrophication. Pol. Arch. Hydrobiol., 29: 541-597. 
